\title{
光学プラスチック
}

魚津吉弘

\section{1. 透明性プラスチック材料}

一般にプラスチック材料は安価であり，ガラス製部品の コスト低減のための代替品と考えられがちである。しか し，プラスチック材料はそれ自体のコストのみを考えると ガラス材料と大差ないあのである。ガラスからプラスチッ クに材料が置き換わっていく理由は以下に示すプラスチッ ク材料特有の性質が大きな要因になっていることがほとん どである。

(1)易加工性からくる成形加工コストが低いこと，ならび に形状付与が非常に容易なこと, (2)衝撃がかかって屯割れ にくいこと, (3)軽量であること, (4)染料や微粒子などの機 能性材料を添加し機能性の付与が容易であること。

透明性プラスチックを特殊形状に加工したり，機能性材 料を添加したりして，光学分野に適用したものを光学プラ スチックという。この光学プラスチックの分野には大きく 分けて, 映像表示, 画像伝送, 情報伝送の分野がある。

\section{2. 画像表示分野}

画像表示分野は光学プラスチックがあっとも多く用いら れている領域である。大型スクリーンで用いられるフレネ ルレンズ, レンチキュラーレンズはプラスチックの独壇場 である。これらのレンズは耐衝撃性が必要であるととあに 複雑な形状から加工性のよいことが必要である。また，レ ンチキュラーレンズに関しては拡散材や吸収剂の混入が必 須でありプラスチックの特性が存分に発揮されている。小 型のスクリーンとしてはノートブックコンピュータや携帯 電話用のあのがあるが，これらに対してあ軽量化という目 的と複雑な形状加工や機能性物質の添加のためにプラス

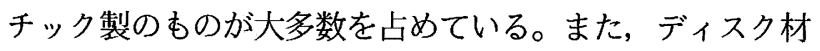
料であ割れないことが必須でありプラスチックが用いられ ている。

\section{3. 画像伝送分野}

メガネレンズでは軽さと耐衝撃性が主要因として, 現在 はほとんどがプラスチックとなっている。また，コンタク トレンズは生体適合性の面からプラスチックの独壇場であ る。酸素透過性などの機能性付与が進められている。ピッ
クアップレンズむ形状の複雑な非球面レンズが適用されて おり，プラスチックの易加工性および軽量という特性を活 功ている。

近年, 屈折率分布型プラスチックロッドレンズアレイの 工業的な製造技術が開発され，ファクシミリやスキャナー の重要な部品となっている。このロッドレンズはガラス製 のあのよりあ性能のフレが抑えられており，レンズアレイ のディメンジョンが固定され機器への組み込みが非常に容 易になっており，プラスチック製レンズ採用への動機と なっている。

\section{4. 情報伝送分野}

プラスチック光ファイバー (POF) は芯鞘構造からな り, 芯材にはPMMAを鞘材にはフッ素系の透明性ポリ マーが用いられている。伝送距離は $100 \mathrm{~m}$ 以下之短いが, 直径が大きく受発光素子とのカップリングが容易であるこ と，振動や衝撃に強いなどガラス製の光ファイバーにはな いメリットが存在する。現在，ヨーロッパで車載用途が立 ち上がりを迎え，世界的なトレンドとなりつつある。さら にホームネットワークの媒体の有力な候補となっている。 近年，プラスチックの伝送性能の限界を覆すようなオー ルフッ素置換のポリマーが開発されてきた。このポリマー は赤外域にあ吸収をあたず透過特性が良好である。このポ リマーを用いたオールフッ素 GI-POF は赤外光の伝送も可 能で，その透明性から数百 $\mathrm{m}$ の伝送が可能となっている。

\section{5. 今後の展開}

光学プラスチックは以上述べたように，従来のガラス製 の材料では発現できなかった特性発現を可能としてきた。 プラスチック材料の採用による機能性の付与ならびに価格 の低減により, 従来の光学ガラスでは切り開けなかった市 場の開拓に成功し，世の中に広く浸透してきた。これら光 学プラスチックの開発は, 多くのあのが日本発のあのであ り常に世界をリードしてきた。今後もプラスチックの特性 を活かした光学部品の提案がなされ, プラスチックの光学 分野への適用は増えていくあのと予想される。われわれ， 日本の研究者がますますこの分野の開発をリードしていき たいものである。

UOZU, Yoshihiro 三菱レイヨン(株)中央技術研究所・主任技師。専門はオプティクス材料.

Optical Plastics 